\title{
The Influence of Strategic Leadership on Building Employees' Entrepreneurial Orientation: A Field Study at the Jordanian Public Sector
}

\author{
Sahar Mohammad Abu Bakir ${ }^{1}$ \\ ${ }^{1}$ Associate Professor, Business Administration Department, Faculty of Business, Amman Arab University, Jordan \\ Correspondence: Sahar Mohammad Abu Bakir, Associate Professor, Business Administration Department, \\ Faculty of Business, Amman Arab University, Jordan.
}

Received: March 27, 2017

Accepted: April 28, $2017 \quad$ Online Published: May 13, 2017

doi:10.5539/ibr.v10n6p62

URL: https://doi.org/10.5539/ibr.v10n6p62

\begin{abstract}
The public sector in Jordan is confronting many problems; reports show that citizens are not contented with the number and quality of current services. Consequently; persistent initiatives to uphold the sector performance took place at all levels, relying on the inventive employees and leadership to achieve the intended improvement. So this study seeks to test the impact of strategic leadership (charismatic, visionary, change agent and servant) on building entrepreneurial orientation (proactiveness, innovativeness and risk taking) in Jordanian public sector employees.

A random sample was selected of 500 employees working at health, education, agriculture and other service governmental organizations. To obtain the required results multiple regression was calculated using (21) SPSS version.

It was found that the charismatic, change agent, servant styles positively influence employees proaciveness, with no influence on the other two entrepreneurship dimensions. While visionary style has no significant influence on all entrepreneurship dimensions. However the public sector reform is achievable, through comprehensive strategies, successful implementation, and effective continuous control. Innovative departments need to be established and financed away from bureaucratic environments.
\end{abstract}

Keywords: entrepreneurial orientation, Jordanian public sector, strategic leadership

\section{Introduction}

It is known that one of the public sector responsibilities and at the same time challenges in any country is to provide citizens with basic services on time and at satisfactory level of quality (Jarrar \& Schiuma, 2007; Northcott \& Ma'amora, 2012). Citizens are now different than before, they are knowledgeable, empowered, their demands and expectations are escalating, they are alert enough to judge the goodness of the state's services and express their un-satisfaction frankly (Im, 2014). Other stakeholders rather than citizens come in to the scene; they also have expectations, their satisfaction is crucial as well (Tizard, 2012).

Some researchers (Bhuiyan \& Amagoh, 2011 ; Nusair, Ababneh, \& Kyung, 2012 ; Agolla \& Van, 2016 ; Shannak, 2013) argued that service quality is not the only dilemma that confronts the public sector, the sector is answerable for environment safety, efficiency, cost reduction, productivity, fast responsive to citizens requirements and coping with technological advancement .. etc. Furthermore it was assumed that bureaucracy represents the pivotal barrier confronting the public sector and restricting its attempts in serving citizens (Page \& Page, 2016). In spite of these challenges the public sector is trying hard to go beyond the traditional patterns of management; there is a tendency towards public sector reform all over the world.

Joining efforts of local governments with external assistance are taking place to refresh services quality (Lemay, 2009; Cummings, 2015).

Lindorff (2009); Aziz, Silong, Karim, \& Hassan, (2012) suggested that the solution embedded in unconventional leadership style that is able to energize the sector employees, and stimulate their innovation to be ready for change and to be part of the reform.

Quinn and Courtney (2016) confirmed that it is not the responsibility of leadership alone; they put insight on 
building entrepreneurial orientation in public sector employees.

Cumming (2015) supposed that reforms counted on employees entrepreneurial orientation; the empowered, risk-takers, innovative, learned employees, can only create the radical shift in public sectors' amelioration.

The questions that rises what is the convenient leadership style that could manage this change and enhance employees' innovative orientation?

Nutt and Backoff (1993) introduced the strategic leadership which is associated with change, creativity and innovation as the saver of public sector organizations. Simsek, Jansen, Minichilli, \& Escriba - Esteve, (2015) added that strategic leadership is able to create entrepreneurial situations in any organization.

Accordingly this study tried to examine the degree to which Jordanian public sector employees classify their leaders as strategic, and the influence of strategic leaders in building employees' entrepreneurial orientation.

\section{Theoretical Background and Literature Review}

\subsection{Public Sector's Challenges}

In spite of the different considerations of public sector challenges' essence, there is no doubt that many stumbling blocks restrain the sector innovation everywhere.

McNary (2008) conceived that monopoly in providing specific services associated with lack of competitors defeat any initiatives for change, no expected profits will surely thwart creativity and innovation in the public sector.

Caemmerer and Wilson (2011) believed that the contradiction between efficiency and effectiveness is the core of the public sector's problems.

Moreover, Lapsley and Oldfield (2001); Elsheikh, Cullen, \& Hobbs, (2008) considered that lack of qualified talented human resources restricts the best utilization of resources, diminishs rational decisions and accordingly service quality.

Aladwan and Forrester (2016) concluded that lack of effective strategic planning, joined with scarce financial resources and shortage of empowered employees hindered Jordanian public organizations attempts towards excellence.

Aziz et al., (2012) assessed the challenges of the public sector in 15 countries distributed in 6 continents; they concluded that bureaucracy is the common fundamental ever ending problem. Also Zamhury, Hashim, \& Ahmad (2009) proved that bureaucracy is the source of most complaints concerning the Malaysian public sector services.

Majdalawi, Almarabeh, Mohammad \& Quteshate, (2015); Shannak (2013) perceived bureaucracy as one of the major obstacles that face e- government implementation in Jordan.

\subsection{Public Sector's Reform}

The former challenges pushed governments for public sector reform through internal efforts, and sometimes supported by external initiatives from international agencies as the World Bank and or donations (Owusu, 2012).

Public sector's reform had its magnitude in research as well; Lapsley and Oldfield (2001); Radnor and McGuire (2004) illustrated the British initiatives for public sector reform, while Luke and Verreynne (2006) were concerned with the go vernment organizations reform at New Zealand, Steijn and Leisink (2007) summarized the changing reform actions in Dutch public sector.

Zamhury et al., (2009) were interested with the reform at the Malaysian public-sector, Zampetakis and Moustakis (2007) involved in the ameliorating activities in Greece public sector. Owusu (2012) lighted Ghana's public sector improvement experience. Wallis and McLoughlin (2007) explained the Irish governmental strategic reform. $\operatorname{Im}$ (2010) explored the Korean government attempts for public sector reform.

Jordan has its initiatives too; the Jordanian government set strategies for comprehensive reform including structure, processes, management, and leadership (Aladwan \& Forrester, 2016).

Despite the differences between countries in terms of the content and the specific objectives of reform programs, a consent existed to reduce bureaucracy, manage human resources in a modern developmental manner, minimize cost, and to exploit in the scarce resources efficiently (Im, 2014).

Because public sector reform is a complicated change process, it requires strategic activities in terms of strategic plans, felicitous implementation and strategic thinkers' supervision; in short it needs strategic leadership (Laitinen, Nyholm, Stenvall \& Kaivo-oja, 2015). 


\subsection{Strategic Leadership}

Strategic leadership is the combination between the concept of leadership and strategy; it is usually used to describe the decisions and actions of top management positions in any organization (Bratton, Grint \& Nelson, 2005).

According to Buchanan and Huczynski (2010) the basis of leadership is influence the leader practice on followers to affect their attitudes and behavior, with the aim to direct all the efforts towards attaining the organizations objectives.

For the best accomplishment leaders counted on several sources of influence beyond the formal legitimate, leaders invested in their reward, expert, and referent powers in order to guarantee followers optional cooperative (Al-Khasawneh \& Moh'd, 2013).

Page and Page (2016) viewed leadership in the public sector as collective efforts and mutual effect between leaders and followers expressed in joint actions for citizens' continuous well- being.

When it comes to strategic, the connotation gives leadership its specialty than other styles; it is the combination of several leadership styles working together in a synergistic system for a better future (Ireland \& Hitt, 2005).

Vera and Crossan (2004) conceived that the strategic leader goes beyond the ordinary leader. The strategic leader is accountable for the future of the organization. Spiritually and ethically he/ she is responsible for internal and external stakeholders satisfaction.

\subsubsection{Characteristics of Strategic Leaders}

Nutt and Backoff (1993) introduced the notion strategic leaders as a comprehensive style encompasses several styles employed to elevate human and organizational performance in the public sector.

Joyce (2004) indicated that the public sector is in urgent need for multi skills strategic leaders to guide employees and the intended change.

Yukl (2006) articulated that a single leadership style is not sufficient for strategic transformational change; the strategic leader is a change agent, visionary, servant and ethical possess charismatic traits to persuade, encourage, and motivate followers to perform rather than imposed them to do so.

\subsubsection{The Charismatic Leader}

This leadership style was introduced by MaxWeber's to describe the innate power the leader has (Buchanan \& Huczynski, 2010), this style's influence is different than other styles, it is intangible derived from the unique personal traits and the power of attracting people to affect their attitudes and behavior optionally (Robbins \& Judge , 2013).

Accordance to Daft (2012) charismatic style is linked with leadership referent power, the charismatic leader gains followers' respect, and compliance away from the formal position, he / she has charming effect, and verbal communications skills to induce followers emotions and willingness to act positively for the work's benefit without resistance.

Garg and Jain (2013) results indicated that charismatic public sector's leaders are people oriented had friendly relationship with their followers, trigger them to participate in setting organizational vision, and teach them proper methods to achieve it.

Kesting, Ulhoi, Song, \& Niu, (2016) denoted that it is difficult for charismatic leadership style to achieve strategic performance unless it is associated with other styles.

\subsubsection{Visionary Leader}

Khatri, Templer, \& Budhwar, (2012) believed that strategic actions needs an integrated charismatic and visionary styles, one off the two will not be enough.

The visionary leader has the ability to look at the external environment, visualize the expected changes and draw scenarios how to avert threats and exploit in the opportunities through collective efforts (Kunnanatt, 2016).

According to Milner \& Joyce, (2012) the visionary is an outcome oriented leadership style. The leader determined organization's future actions, and then work out with followers towards effective implementation.

In the public sector the visionary leader set forth multi-level visions, extended to encompass citizens' welfare and the whole society satisfaction (Lemay 2009). 


\subsubsection{Change Agent Leader}

The strategic leader as a change agent carries out the process of change, induces staff to be partners not just implementers (Stewart \& O'Donnell, 2007), has persuading competencies to push them to devote time, voluntary efforts towards achieving change objectives (Robbins \& Judge 2013).

Ates (2004) believed that in the public sector change agent role is linked with leaders Expert power, they manage through harmonious teams, and leaders are interested to choose their team members carefully from those who are ready to work together and with their leader towards elevating organizational performance.

\subsubsection{Servant Leader}

Lemay (2009) perceived strategic leaders in the public sector as (public servants), outspread their vision to the community's benefit, working hard to fulfill citizens expectations.

Furthermore Han, Kakabadse, \& Kakabadse, (2010) mentioned that servant leader assists followers to manage the balance in their work life, inculcates in them serving others, and promotes their internal locus of control.

Liden, Wayne, Zhao, \& Henderson, (2008) pointed that servant leaders in the public sector are selfless, they prioritized others' interest, and implied to create value to the community, behave ethically with fairness, they are open minded willing to learn and teach followers to be future leaders.

\subsection{Entrepreneurial Orientation}

Entrepreneurship is an old concept used to describe the work of people who have un-conventional methods in searching for opportunities, those who are willing to create value by exploiting resources in an innovative manner (Diefenbach, 2011).

Wickham (2006) ; Ries (2011) defined entrepreneurship as individual's ability and desire to establish a new business based on uncommon techniques in utilizing resources, while estimating risks with the aim of profits yield.

Hisrich, Peters, \& Shepherd, (2013) pointed that although entrepreneurship was connected with small, privately owned new organizations.

Large organizations can be entrepreneurial oriented, and engage in organizational entrepreneurship (Intrapreneurship). According to Cadar and Badulescu (2015) (Intrapreneurship) is associated with entrepreneurship spirit, building on the enthusiasm of employees who are willing to create value, and on innovate and proactively planning for continuous revival of the processes and products. Kacperczyk (2012) argued that employees are able to act as entrepreneurs in matured organizations; but they need autonomy, tolerance, and management support to search for non-manifested opportunities and take advantage before competitors did so.

Diefenbach (2011); Greiling (2013) supposed that public sector is not a way from operating in an entrepreneurship spirit and actions, entrepreneurship in the public sector is leaned on individuals who are recognized by their proactiveness, creativity, innovativeness and preparedness to take risk, and they are witty to operate freely from bureaucratic constraints.

\subsubsection{Elements of Entrepreneurial Orientation}

Miller (1983) proposed 3 dimensions of individual and organizational entrepreneurship (proactiveness, innovation and risk taking). Kearney, Hisrich, \& Roche, (2010) stressed on the 3 elements to establish entrepreneurship in the public sector, their results inferred that all the three can be applicable in the public sector and have noticeable impact on performance.

Barringer and Ireland (2012) remarked that entrepreneurial focused organizations have proactive, innovative employees and at the same time risk takers; looking forward to think and act outside the box of bureaucracy.

\subsubsection{Proactiveness}

Proactiveness is people initiatives to drive forward the future rather than responding, proactive human resources are masterful in capturing un-noticed opportunities, and in creating unique successful stories (Bagheri \& Pihie , 2011).

According to Kreiser and Davis (2010) proaciveness can be expressed through being the first in the market, strategically positioned through novelty, depending on demand forecasting, and optimistic expectations and act accordingly. Whilst in the public sector proactiveness is perceived as the process of contemplating what future needs, set forth innovative strategies that exceed the expectations of citizens to luckily acquire new services, re-new the present, or introduce services in exceptional methods (Diefenbach 2011). 
In the public sector proactive leader's efforts worked in synergy with the initiatives of innovative employees, who are self-directed, express their future visions in creative plans and problems solutions (Morris \& Jones, 1999).

\subsubsection{Innovativeness}

Innovation is the essence of entrepreneurship, it goes beyond modification or improve the existing to novelty with usefulness, diversify value creation in unusual ideas and actions (Drucker 1985).

Karyotakis and Moustakis (2016) imagined that innovation can only prosper in a non-classical environments, flexibility, team work, open communication, enough resources, and trained empowered people are indispensable to induce innovation in the public sector.

Sangiorgi (2015) argued that innovation in the public sector is the output of innovative culture and cooperative endeavors of different stakeholders calling for change. Moreover according to Diefenbach (2011) innovation in the public sector presented in new solutions to the sector problems, new structures reengineering and process amelioration, and for sure new services and developed forms of the current services.

\subsubsection{Risk Taking}

Kacperczyk, (2012) stated that risk is a distinguishable elements of entrepreneurs, it is linked with uncertainty of success, and with the degree of sacrifice in case of failure, in addition to the loss of resources and time that were devoted for the new intuitive.

Mason (2006) articulated that the risk in public sector entrepreneurship is low, for no financial loss is expected if individuals failed in providing services, nor any punishment procedures, and there is no connection between the salaries continuity and achievements, the public sector's employees are somehow secured.

However Diefenbach, (2011) mentioned that the public sector risk presented in conjunction with novelty; where time, resources are dedicated to exploit in new opportunities, while the consequences are ambiguous.

Wickham (2006) indicated that in the public sector risk encompasses political loss too; failure to fulfill the promising outcomes will result in weaken the legitimate authority entrepreneurs have.

\section{Significant of the Study}

The public sector in Jordan is facing number of barriers which inhibit the availability of basic services at a convenient level. Lack of the obtainable resources, coincide with the lack of motivated skillful employees as some researchers pointed out (Shannak, 2013; Elsheikh et al., 2008; Majdalawi et al., 2015) created sophisticated troubles to the sector.

Despite the successive attempts of reform adopted by governments, incorporating by international agencies aid, citizens' complains never stopped, conjunction with the media role in focusing on the negative side of the public sector shortages.

The presented solutions all underlined the critical contribution of the sector employees to elevate services quality. There is no doubt that low financial earning creates for those a state of frustration, accordingly it is difficult to stimulate their efforts for more, but it is not impossible.

Other countries' successful reform proved that leaders' dedication, their attempts to teach, inspire, and spur employees tendency to serve, represent a major support to achieve reform goals.

\section{Study's Measurements and Hypotheses}

The study aimed to test the influence of strategic leadership on building employees entrepreneurial orientation.

There is no particular measure of strategic leadership, literature pointed that one leadership style will not be convenient to run the organization's future, a compound style of traits, skills, capabilities, values can be appropriate to lead public sector's organizations. The researcher used charismatic, visionary, change agent and servant styles together to describe strategic leader's features.

When it comes to the dependent variables, Miller's (1983) model of (proactiveness, innovativeness and risk taking) utilized to characterize employees' entrepreneurial orientation.

\subsection{Study's Hypotheses}

The main Hypothesis H: Strategic leadership (charismatic, visionary, change agent and servant) positively influence building employees' entrepreneurial orientation (proactiveness, innovativeness and risk taking).

The main hypothesis is divided into 3 sub hypotheses as follows: 
$\mathrm{H}_{1}$ : Strategic leadership (charismatic, visionary, change agent and servant) positively influence building employees' proactiveness.

$\mathrm{H}_{2:}$ Strategic leadership (charismatic, visionary, change agent and servant) positively influence building employees' innovativeness.

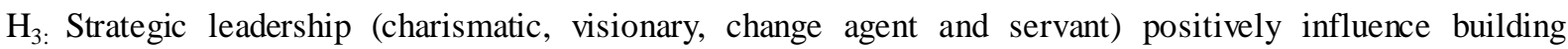
employees' risk taking.

\subsection{Study's Model}

Independent Variable/s

Strategic leadership

\begin{tabular}{l}
\hline Charismatic style \\
Visionary \\
Change agent \\
Servant
\end{tabular}

\section{Methodology}

\subsection{Data Collection}

To collect the needed data, an enquiry was conducted using a 3-part questionnaire, the first part expressed the sample structure and characteristics.

Using likert 5 points scale (35) statements were developed to measure the independent and dependent variables as follows:

The second part contained (20) statements to estimate strategic leadership elements, 5 statements for each style (charismatic, visionary, change agent and servant).

The third part enclosed (15) statements to assess the level of entrepreneurial orientation's 3 dimensions (proactiveness, innovation and risk taking).

\subsection{Study's Population and Sample}

The study's population comprised public sector organizations which are responsible for providing the essential services, 500 employees were randomly selected from health, education, agriculture and cooperation corporation. 500 questionnaires were distributed, 390 were returned back, and 373 were statistically analyzed.

The respondents were asked to express if they perceived their leaders as strategic, and if their leaders are working for catalyzing proactiveness, risk taking and inno vative performance, and enhance their entrepreneurial spirit.

\section{Statistical Analysis Results}

\subsection{Tool's Reliability}

Cronbach's alpha used in order to examine the internal consistency and reliability of the tool questions, the results illustrated in table (1) show that all the values are $>60 \%$ which means according to (Sekaran,2003) that the study's tool is reliable

Table 1. Cronbach's alpha results

\begin{tabular}{lclc}
\hline Inde pendent Variable/s & $\begin{array}{l}\text { Cronbach's } \\
\text { alpha }\end{array}$ & Dependent Variable /s & Cronbach's alpha \\
\hline Strategic Leadership ( Total) & 0.94 & Entrepreneurial orientation ( Total) & 0.79 \\
$(15$ items $)$ & & 0.79 \\
\hline Charismatic & 0.83 & Pro-activeness & 0.70 \\
Visionary & 0.85 & Innovation & 0.83 \\
Change agent & 0.80 & Risk taking & \\
Servant & 0.79 & &
\end{tabular}

The results of frequencies and percentage show that $79.9 \%$ of the respondents were males, while just 20.1 were females, $68.9 \%$ of the sample were less than 40 years old , $67.8 \%$ have university degrees and $93 \%$ of their practical experience was more than 5 years, all of them are Jordanians. 


\subsection{Descriptive Analysis Results}

To rate the sample acceptance for the study's questions; the arithmetic mean, and standard de viations of the responses calculated, the results in Table (2) show the total means of the strategic leadership, and entrepreneurial orientation dimensions.

It is appeared that the total means of strategic leadership's 4 dimensions are higher than 3, which inferred that the respondents perceive their leaders as strategic, able to set a manageable vision, communicate the future road map clearly, have personal convincing power, working with mutual respect, and open communication, able to interact positively with everybody, and leading the change rationally.

It is apparent that respondents perceived their leaders as (servants) than any other leadership style, leaders prompt employees to lead with servant mindset to provide services to country citizens with altruism, put the public benefits first and foremost, enhance employees' commitment to home through providing better health and education and other related services to the inhabitants.

When it comes to the dependent variable/s (entrepreneurial orientation) it is obvious from the means in table (2) that the sample members admit that their leaders instill entrepreneurial spirit in them, receive carefully employees creative ideas and induce them to take acceptable risk to engage in innovative experiments for the sake of generating new services, or new mechanism in providing current services, or methods to maximize the yield of the scarce resources.

Table 2. Descriptive statistics results

\begin{tabular}{llllll}
\hline Inde pendent Variable/s & Mean & S. D & Dependent Variable /s & Mean & S.D \\
\hline Charismatic & 3.66 & 0.75 & Pro-activeness & 3.69 & 0.73 \\
Visionary & 3.81 & 0.79 & Innovation & 3.62 & 0.61 \\
Change agent & 3.69 & 0.81 & Risk taking & 3.86 & 0.78 \\
Servant & 4.47 & 0.92 & & & \\
\hline
\end{tabular}

6.4 Hypotheses Testing

6.4.1 The main Hypothesis $(\mathrm{H})$ results

Strategic leadership has a positive influence on building employees' entrepreneurial orientation. Simple regression with $0.05 \mathrm{p}$ value used to test the influence of strategic leadership as a total variable on building employees' entrepreneurial orientation with all its 3 dimensions, based on the rule to accept the hypothesis if the sig value of $T$ is less than 0.05 .

Table 3. The main hypothesis testing results

\begin{tabular}{ccccc}
\hline \multicolumn{5}{c}{ Model Summery \& ANOVA results } \\
\hline $\mathrm{R}$ & $\mathrm{R}^{2}$ & Adjusted $\mathrm{R}^{2}$ & F calculated & $\mathrm{F} \mathrm{sig}$ \\
\hline 0.442 & 0.195 & 0.193 & 84.739 & 0.000 \\
& & Coefficient & T - calculated & T sig \\
Constant & $\mathrm{B}$ & Beta & 19.408 & 0.000 \\
\hline
\end{tabular}

The summarized results in table (3) exhibit the values of the followings:

The value of $\mathrm{F}(84.739)$ at $0.000 \mathrm{sig}$ level; which is $<0.05$ evidence the linear relationship between the two variables.

(R) Pearson correlation (0.442) which explained a significant relation between strategic leadership and building entrepreneurial orientation.

$\mathrm{R}^{2}$ value $(0.195)$ which indicated that $19.5 \%$ of the variation of entrepreneurial orientation is due to strategic leadership, while $80.5 \%$ of entrepreneurial orientation caused by other factors than strategic leadership.

$\mathrm{T}$ value (19.408) and $\mathrm{t}$ (sig) 0.000 which is $<0.05$ (based on the above mentioned rule) it is indicated that strategic leadership significantly influences building employees' entrepreneurial orientation.

\subsubsection{Sub Hypothesis Testing Results}

Multiple regression with $\mathrm{p}$ value 0.05 used to test the impact of strategic leadership dimensions on each dimension of entrepreneurial orientation, and based on the previous rule the hypothesis will be accepted if $t$ sig level is $<0.05$.

\subsubsection{The First Sub Hypothesis Results}

$\mathrm{H}_{1}$ : Strategic leadership (charismatic, visionary, change agent and servant) positively influence building employees' proactiveness . 
Table 4. Results of testing $\mathrm{H}_{1}$

\begin{tabular}{|c|c|c|c|c|}
\hline \multicolumn{5}{|c|}{ Model Summery \& ANOVA results } \\
\hline $\mathrm{R}$ & $\mathrm{R}^{2}$ & Adjusted $\mathrm{R}^{2}$ & F calculated & F sig \\
\hline 0.864 & 0.747 & 0.744 & 255.076 & 0.000 \\
\hline \multicolumn{5}{|c|}{ Coefficient } \\
\hline Sub-independent Variables & $\mathrm{B}$ & Beta & $\mathrm{T}$ - calculated & $\mathrm{T} \operatorname{sig}$ \\
\hline Constant & 0.341 & & 3.156 & .002 \\
\hline Charismatic & & 0.208 & 4.744 & 0.000 \\
\hline Visionary & & 0.082 & 1.640 & .102 \\
\hline Change agent & & 0.345 & 7.790 & 0.000 \\
\hline Servant & & 0.326 & 6.511 & 0.000 \\
\hline
\end{tabular}

Table 4 presents the results of testing the first sub hypothesis $\mathrm{H}_{1}$ as follows:

$\mathrm{R}$ value (0.864) indicated that there is a strong correlation between strategic leadership dimensions and proactiveness, the value of $R^{2}$ denotes that $74.7 \%$ of the variation of proactiveness caused by strategic leadership dimensions.

F value (255.076) at $0.000 \mathrm{sig}$ is an indication of the linear relationship between strategic leadership dimensions and proactiveness.

When it comes to $t$ values, and $t$ sig it is obvious that the charismatic, change agent and servant dimensions have an impact on building proactiveness in Jordanian public sector employees; depending on $\mathrm{t}$ sig levels which are for the three dimensions $<0.05$.

While visionary dimension has no effect on building entrepreneurial orientation due to $t$ sig $=(.102)$ which is $>$ 0.05

The Values of Beta in the table clarify that the change agent dimension has the higher effect on building employees proactiveness; Beta $=(0.345)$, followed by servant $(0.326)$, and charismatic style has the least effect on proactiveness as Beta $=(0.208)$.

6.4.2.2 The Second Sub Hypothesis Results

$\mathrm{H}_{2:}$ Strategic leadership (charismatic, visionary, change agent and servant) positively influence building employees' innovativeness.

Table 5. Results of testing $\mathrm{H}_{2}$

\begin{tabular}{lcccc}
\hline \multicolumn{1}{c}{$\mathrm{R}$} & \multicolumn{3}{c}{ Model Summery \& ANOVA results } \\
\hline \multicolumn{1}{c}{0} & $\mathrm{R}^{2}$ & Adjusted $\mathrm{R}^{2}$ & F calculated & $\mathrm{F}$ sig \\
\hline & 0.033 & 0.022 & 2.96 & 0.020 \\
\hline Sub-independent Variables & $\mathrm{B}$ & Coefficient & & $\mathrm{T}$ sig \\
\hline Constant & 3.155 & Beta & T - calculated & 0.468 \\
Charismatic & & & & 0.726 \\
Visionary & & 0.062 & 1.616 & 0.107 \\
Change agent & & 0.158 & 0.682 & 0.496 \\
Servant & 0.059 & 1.233 & 0.219 \\
\hline
\end{tabular}

The results in table 5 indicated that there is a weak relationship between strategic leadership's 4 dimensions and innovativeness, $\mathrm{R}$ value $=(0.182)$.

$F$ value (2.96) at 0.020 sig underlined the linear relationship between the tested variables.

However the values of $\mathrm{t}$ sig which are for all strategic leadership dimensions $>0.05$ Inferred that strategic leadership dimensions have no influence on building innovativeness in public sector employees.

\subsubsection{The Third Sub Hypothesis Results}

$\mathrm{H}_{3}$ : Strategic leadership (charismatic, visionary, change agent and servant) positively influence building employees' risk taking. 
Table 6. Results of testing $\mathrm{H}_{3}$

\begin{tabular}{|c|c|c|c|c|}
\hline \multicolumn{5}{|c|}{ Model Summery \& ANOVA results } \\
\hline $\mathrm{R}$ & $\mathrm{R}^{2}$ & Adjusted $\mathrm{R}^{2}$ & F calculated & F sig \\
\hline 0.161 & 0.026 & $\begin{array}{c}0.015 \\
\text { Coefficient }\end{array}$ & 2.314 & 0.057 \\
\hline $\begin{array}{l}\text { Sub-independent Variables } \\
\text { Constant }\end{array}$ & $\begin{array}{c}\text { B } \\
4.206\end{array}$ & Beta & $\mathrm{T}$ - calculated & $\mathrm{T} \operatorname{sig}$ \\
\hline Charismatic & & 0.032 & 0.372 & 0.710 \\
\hline Visionary & & 0.187 & 1.901 & 0.058 \\
\hline Change agent & & 0.170 & 1.956 & 0.051 \\
\hline Servant & & 0.082 & 0.832 & 0.406 \\
\hline
\end{tabular}

The results in table 6 indicated first: that the relationship between strategic leadership dimensions and risk taking is weak, $\mathrm{R}=(0.161)$.

Second: there is no influence of strategic leadership dimensions on building risk taking in public sector employees; relying on t significant values which are for all strategic leadership dimensions $>0.05$.

\section{Results Discussion}

The public sector in Jordan is confronting many problems, reports show that citizens are not contented with the number and quality of current services. Consequently; persistent initiatives to uphold the sector performance took place at all levels, "King Abdullah the second award for excellence " considered one of these efforts, it relies mainly on the inventive human resources to raise the quality of the running services and broadened to new ones.

Likewise Jordanian public sector has its magnitude in research; the results of Nimri, Bdair \& Al Bitar, (2015) pointed that public sector employees in Jordan are intrinsically motivated than extrinsic financial, employees are pushed by their desire to serve the country, however leaders can optimistically invest in non-costly solicitation to energize employees and upgrade their outputs.

Yaghi, Goodman, Holton, \& Bates, (2008) findings emphasized the role of Jordanian public sector's managers in promoting employees learning, and in encouraging them to use the learned skills to boost the sector's performance.

Ababaneh (2010) research which was conducted at 4 Jordanian public hospitals assured the role of leadership in quality improvement, he pointed that leaders are the backbone in setting a strong innovative culture, sustaining employees' creativity to consolidate preferable health services.

Theoretically researchers believed that leaders in the public sector are change drivers, they take charge to construct innovative environment, activate all the possible resources, and equip all organization's members for services regeneration.

Therefore; this study attempts to inspect the influence of Jordanian public sector strategic leaders on building employees entrepreneurial orientation. 4 dimensions used to express the strategic leadership (charismatic, visionary, change agent and servant), and 3 dimensions (proactivness, innovation, and risk-taking) utilized to assess the degree of entrepreneurial orientation in public sector employees.

The arithmetic mean results disclosed that public sector leaders possess high level of charismatic, visionary change agent and servant leadership styles features.

It is obvious that servant style prevailed; the respondents believe that their leaders are to lead by example; leaders have an altruism approach in serving internal employees and external stakeholders.

Whereas simple regression results of the main hypothesis indicated that strategic leadership positively have a significant influence on building employees entrepreneurial orientation.

With regard to the examination of sub hypothesis results it was found first that the charismatic, Change agent, servant styles positively influence employees' proactiveness, with no influence on other two entrepreneurship dimensions (innovativeness and risk taking).

Second: visionary style has no significant influence on all 3 entrepreneurship dimensions.

The findings can be attributed to the limitation of financial resources; expenses are restricted specifically with the items listed in the organization's budget. The resources are allocated in advance, under the government control, leaders don't have the authority to set their department future plans outside the general strategy of the organization, and at the same time don't have the ability or the authority to finance any innovative action, or even to ask for finance as long as the outcomes are unknown and not guaranteed. 
This study's hypotheses go in line with Luke and Verreynne (2006) in terms of the prospect application of strategic entrepreneurship in public sector organizations, and with the notion that the nexus between strategic thinking with leadership interventions is the pivotal basis for public sector reform.

The study's results agreed with Zampetakis and Moustakis (2007) findings that secured public sector employees have proactive initiatives, and can be energized easily by non-financial stimulus.

Also the results of this study match Diefenbach (2011) results in terms of the crucial contribution of public sector managers in assisting employees' creativity, and in consolidating entrepreneurial spirit within the sector organizations.

Moreover the results didn't go with Muchiri (2013) conclusions; his findings confirmed that leaders are more effective in inculcating entrepreneurship dimensions both at the individual and organizational levels and produce better performance.

This research's results didn't match either the findings of Nusair et al., (2012) which proved that transformational leadership had a significant influence on innovative behavior of the Jordanian public sector employees.

Whereas the findings of this study didn't support leadership influence on innovation and risk-taking dimensions.

\section{Recommendations}

However the public sector reform is achievable, stimulating innovation necessitates more than setting plans; it needs a comprehensive organizational strategies, successful implementation, and effective continuous control.

Innovative departments need to be established and financed away from bureaucratic environments.

The innovative process can only build on well trained, proactive, creative and risk takers people, operating without the constraints of formality and centralization, flexible structures, joined with a learning culture, special reward system with tolerance, and the most critical change facilitator which is entrepreneur strategic leaders working in synergy with external stakeholders to assess citizens' needs and respond accordingly.

For future research it is recommended to use some other leadership styles, and other factors than leadership that have an impact on the public sector reform.

\section{References}

Ababaneh, I. R. (2010). The role of organizational culture on practicing quality improvement in Jordanian public hospitals. Leadership in Health Services, 23(3), 244-259. https://doi.org/10.1108/17511871011061064

Agolla, J. E., \& Van Lill, J. B. (2016). An empirical investigation into innovation drivers and barriers in public sector organizations. International Journal of Innovation Science, 8(4). https://doi.org/10.1108/JJIS-06-2016-0006

Aladwan, S. A., \& Forrester, P. (2016). The leadership criterion: challenges in pursuing excellence in the Jordanian public sector. The TQM Journal, 28(2), 295-316. https://doi.org/10.1108/TQM-08-2014-0064

Al-Khasawneh, A. L., \& Moh'd Futa, S. (2013). The impact of leadership styles used by the academic staff in the Jordanian public universities on modifying students' behavior: A field study in the northern region of Jordan. International Journal of Business and Management, 8(1), 1-10.

Ateş, H. (2004). Management as an agent of cultural change in the Turkish public sector. Journal of public administration research and theory, 14(1), 33-58. https://doi.org/10.1093/jopart/muh003

Aziz, S. F. A., Silong, A. D., Karim, N. A. A., \& Hassan, H. (2012). Leadership Practices in Public Sector in Selected Countries: An Integrative Literature Review. Journal of Management Policy and Practice, 13(1), 113-126.

Bagheri, A., \& Pihie, Z. A. L. (2011). Entrepreneurial leadership: towards a model for learning and development. Human Resource Development International, 14(4), 447-463. https://doi.org/10.1080/13678868.2011.601594

Barringer, B., \& Ireland, R. D. (2012) Entrepreneurship: Successfully Launching New Ventures, (4th ed,.) Harlow,Pearson prentice Hall.

Bhuiyan, S. H., \& Amagoh, F. (2011). Public sector reform in Kazakhstan: issues and perspectives. International Journal of Public Sector Management, 24(3), 227-249. https://doi.org/10.1108/09513551111121356

Bratton, J., Grint, K., \& Nelson, D. (2005). Organizational leadership. Mason, Ohio Southwestern/Thompson 
Press.

Buchanan, D. A., \& Huczynski, A. A. (2010). Organizational behavior (7 th ed.)., New York, Pearson education.

Cadar, O., \& Badulescu, D. (2015). entrepreneur, entrepreneurship and intrapreneurship. a literature review. Annals of the University of Oradea, Economic Science Series, 24(2). 658-664.

Caemmerer, B., \& Wilson, A. (2011). An exploration of the service orientation discrepancy phenomenon in the public sector. Services Industries Journal, 31(3), 355-370. https://doi.org/10.1080/02642060802712806

Cummings, C. (2015). Fostering innovation and entrepreneurialism in public sector reform. Public Administration and Development, 35(4), 315-328. https://doi.org/10.1002/pad.1735

Daft, R. (2012). Management, (10th ed.,) Mason Oh. South Western Cengage Learning.

Diefenbach, F. E. (2011). Entrepreneurship in the public sector. In Entrepreneurship in the Public Sector ,un published Doctoral Dissertation, University of St. Gallen, Germany. https://doi.org/10.1007/978-3-8349-6816-6

Drucker, P. F. (1985). Innovation and Entrepreneurship: Practice and Principles, New York, Harper \& Row.

Elsheikh, Y., Cullen, A., \& Hobbs, D. (2008). e-Government in Jordan: challenges and opportunities. Transforming Government: People, Process and Policy,2(2), 83-103. https://doi.org/10.1108/17506160810876176

Garg, S., \& Jain, S. (2013). Mapping Leadership Styles of Public and Private Sector Leaders Using Blake and Mouton Leadership Model. Drishtikon: A Management Journal, 4(1), 48-64.

Greiling, D. (2013, December). Entrepreneurship in the public sector: Basic findings and directions for further research. In Entrepreneurship in the public sector (pp. 271-285). Nomos Verlagsgesellschaft mbH \& Co. KG.

Han, Y., Kakabadse, N. K., \& Kakabadse, A. (2010). Servant leadership in the People's Republic of China: A case study of the public sector. Journal of Management Development,29(3), 265-281. https://doi.org/10.1108/02621711011025786

Hisrich, R., Peters, M., \& Shepherd, D. (2013) Entrepreneurship (8th ed.,) McGraw-Hill Irwin, Boston.

Im, T. (2010). A critical review of new public management styled reform experiments in Korea. Korean Society and Public Administration, 21(1), 1-28.

Im, T. (2014). Bureaucracy in three different worlds: The assumptions of failed public sector reforms in Korea. Public Organization Review, 14(4), 577-596. https://doi.org/10.1007/s11115-013-0246-7

Ireland, R. D., \& Hitt, M. A. (2005). Achieving and maintaining strategic competitiveness in the 21 st century: The role of strategic leadership. The Academy of Management Executive, 19(4), 63-77. https://doi.org/10.5465/AME.2005.19417908

Jarrar, Y., \& Schiuma, G. (2007). Measuring performance in the public sector: challenges and trends. Measuring Business Excellence, 11(4), 4-8. https://doi.org/10.1108/13683040710837883

Joyce, P. (2004). Public sector strategic management: the changes required. Strategic Change, 13(3), 107-110. https://doi.org/10.1002/jsc.670

Kacperczyk, A. J. (2012). Opportunity structures in established firms: Entrepreneurship versus intrapreneurship in mutual funds. Administrative Science Quarterly, 57(3), 484-521. https://doi.org/10.1177/0001839212462675

Karyotakis, K. M., \& Moustakis, V. S. (2016). Organizational factors, organizational culture, job satisfaction and entrepreneurial orientation in public administration. The European Journal of Applied Economics, 13(1), 47-59. https://doi.org/10.5937/ejae13-10781

Kearney, C., Hisrich, R. D., \& Roche, F. W. (2010). Change management through entrepreneurship in public sector enterprises. Journal of Developmental Entrepreneurship, 15(04), 415-437. https://doi.org/10.1142/S1084946710001646

Kesting, P., Ulhøi, J. P., Song, L. J., \& Niu, H. (2016). The impact of leadership styles on innovation-a review. Journal of Innovation Management, 3(4), 22-41. http://hdl.handle.net/10216/81805

Khatri, N., Templer, K. J., \& Budhwar, P. S. (2012). Great (transformational) leadership= charisma+ vision. South Asian Journal of Global Business Research, 1(1), 38-62. 
https://doi.org/10.1108/20454451211205941

Kreiser, P. M., \& Davis, J. (2010). Entrepreneurial orientation and firm performance: The unique impact of innovativeness, proactiveness, and risk-taking. Journal of small business \& entrepreneurship, 23(1), 39-51.

Kunnanatt, J. T. (2016). 3D Leadership-Strategy-Linked Leadership Framework for Managing Teams. Economics, Management, and Financial Markets, 11(3), 30-55. https://doi.org/10.1080/08276331.2010.10593472

Laitinen, I., Nyholm, I., Stenvall, J., \& Kai vo-oja, J. (2015). The Complex Relational Dynamics in Public Sector Reforms. European Integration Studies, (9), 53-59. https://doi.org/10.5755/j01.eis.0.9.12795

Lapsley, I., \& Oldfield, R. (2001). Transforming the Public Sector: Management Consultants as Agents of Change. European Accounting Review, 10, 523-543. https://doi.org/10.1080/713764628

Lemay, L. (2009). The practice of collective and strategic leadership in the public sector. The Innovation Journal: The Public Sector Innovation Journal, 14(1), 1-19.

Liden, R. C., Wayne, S. J., Zhao, H., \& Henderson, D. (2008). Servant leadership: Development of a multidimensional measure and multi-level assessment. The leadership quarterly, 19(2), 161-177. https://doi.org/10.1016/j.leaqua.2008.01.006

Lindorff, M. (2009). We're not all happy yet: Attitudes to work, leadership, and high performance work practices among managers in the public sector. Australian Journal of Public Administration, 68(4), 429-445. https://doi.org/10.1111/j.1467-8500.2009.00649.x

Luke, B., \& Verreynne, M. L. (2006). Exploring strategic entrepreneurship in the public sector. Qualitative Research in Accounting \& Management, 3(1), 4-26. https://doi.org/10.1108/11766090610659724

Majdalawi, Y. K., Almarabeh, T., Mohammad, H., \& Quteshate, W. (2015). E-Government Strategy and Plans in Jordan. Journal of Software Engineering and Applications, 8(04), 211-235. https://doi.org/10.4236/jsea.2015.84022

Mason, P. (2006). Public innovators and entrepreneurship in the public sector. International Journal of Leadership in Public Services, 2(1), 49-51. https://doi.org/10.1108/17479886200600009

McNary, L. D. (2008). Quality management in the public sector: Applying lean concepts to customer service in a consolidated government office. Public Administration Quarterly, 282-301. http://www.jstor.org/stable/41288316

Miller, D. (1983). The correlates of entrepreneurship in three types of firms. Management science, 29(7), 770-791. https://doi.org/10.1287/mnsc.29.7.770

Milner, E., \& Joyce, P. (2012). Lessons in Leadership: Meeting the Challenges of Public Service Management. New York Routledge.

Morris, M. H., \& Jones, F. F. (1999). Entrepreneurship in established organizations: The case of the public sector. Entrepreneurship: Theory and Practice, 24(1), 71-71.

Muchiri, M. K. (2013). Entrepreneurial orientation and leadership: A review, model and research agenda. Small Enterprise Association of Australia and New Zealand 26th Annual SEAANZ Conference Proceedings Sydney.

Nimri, M., Bdair, A., \& Al Bitar, H. (2015). Applying the Expectancy Theory to Explain the Motivation of Public Sector Employees in Jordan. Middle East Journal of Business, 10(13), 70-82. https://doi.org/10.5742/MEJB.2015.92714

Northcott, D., \& Ma'amora Taulapapa, T. (2012). Using the balanced scorecard to manage performance in public sector organizations: Issues and challenges. International Journal of Public Sector Management,25(3), 166-191. https://doi.org/10.1108/09513551211224234

Nusair, N., Ababneh, R., \& Kyung Bae, Y. (2012). The impact of transformational leadership style on innovation as perceived by public employees in Jordan. International Journal of Commerce and Management, 22(3), 182-201. https://doi.org/10.1108/10569211211260283

Nutt, P. C., \& Backoff, R. W. (1993). Transforming public organizations with strategic management and strategic leadership. Journal of management, 19(2), 299-347. https://doi.org/10.1177/014920639301900206

Owusu, F. Y. (2012). Organizational culture and public sector reforms in a post-Washington consensus era: Lessons from Ghana's good reformers. Progress in Development Studies, 12(2-3), 135-151. 
https://doi.org/10.1177/146499341101200304

Page, M. B., \& Page, M. B. (2016). Public leadership: Navigating leadership challenges and operating in service of the common good in an interconnected world. International Journal of Public Leadership, 12(2), 112-128.

Quinn, M., \& Courtney, R. (2016). The Public Sector as an Entrepreneur? In New Perspectives on Research, Policy \& Practice in Public Entrepreneurship, 127-146. https://doi.org/10.1108/s2040-724620160000006006

Radnor, Z., \& McGuire, M. (2004). Performance management in the public sector: fact or fiction? International Journal of Productivity and Performance Management, 53(3), 245-260. https://doi.org/10.1108/17410400410523783

Ries, E. (2011). The lean startup: How today's entrepreneurs use continuous innovation to create radically successful businesses. New York, Crown Business.

Robbins , S. P., \& Judge, T. A. (2013), Organizational behavior (15th ed.). Boston, Pearson Prentice-Hall.

Sangiorgi, D. (2015). Designing for public sector innovation in the UK: design strategies for paradigm shifts Foresight, 17(4), 332-348. https://doi.org/10.1108/FS-08-2013-0041

Sekaran, U. (2003)Research methods for business: A skill building approach (4 th ed.). New York, NY. John Wiley \& Sons.

Shannak, R. O. (2013). The difficulties and possibilities of e-government: the case of Jordan. Journal of Management Research, 5(2), 189. https://doi.org/10.5296/jmr.v5i2.2560

Simsek, Z., Jansen, J. J., Minichilli, A., \& Escriba-Esteve, A. (2015). Strategic leadership and leaders in entrepreneurial contexts: A nexus for innovation and impact missed?. Journal of Management Studies, 52(4), 463-478. https://doi.org/10.1111/joms.12134

Steijn, B., \& Leisink, P. (2007). Public management reforms and public sector employment relations in the Netherlands. International Journal of Public Sector Management,20(1), 34-47. https://doi.org/10.1108/09513550710722698

Stewart, J., \& O'Donnell, M. (2007). Implementing change in a public agency: Leadership, learning and organizational resilience. International Journal of Public Sector Management,20(3), 239-251. https://doi.org/10.1108/09513550710740634

Tizard, J. (2012). The challenges and opportunities in contemporary public sector leadership. International Journal of Leadership in Public Services, 8(4), 182-190. https://doi.org/10.1108/17479881211323571

Vera, D., \& Crossan, M. (2004). Strategic leadership and organizational learning. Academy of management review, 29(2), 222-240.

Wallis, J., \& McLoughlin, L. (2007). A diagnosis of leadership effectiveness in the Irish public sector. Public Management Review, 9(3), 327-351. https://doi.org/10.1080/14719030701425670

Wickham, P. A. (2006). Strategic entrepreneurship: a decision-making approach to new venture creation and management. London: Financial Times.

Yaghi, A., Goodman, D., Holton, E. F., \& Bates, R. A. (2008). Validation of the learning transfer system inventory: A study of supervisors in the public sector in Jordan. Human Resource Development Quarterly, 19(3), 241-262. https://doi.org/10.1002/hrdq.1238

Yukl, G. (2006). Leadership in Organizations (8th ed.,). New Jersey, Pearson Prentice Hall.

Zamhury, N., Hashim, R., \& Ahmad, J. (2009). Towards Better Public Sector Management: A Case of Malaysia. International Journal of Global Management Studies Quarterly, 1(2).64-74

Zampetakis, L. A., \& Moustakis, V. (2007). Entrepreneurial behavior in the Greek public sector. International Journal of Entrepreneurial Behavior \& Research, 13(1), 19-38. https://doi.org/10.1108/13552550710725165

\section{Copyrights}

Copyright for this article is retained by the author(s), with first publication rights granted to the journal.

This is an open-access article distributed under the terms and conditions of the Creative Commons Attribution license (http://creativecommons.org/licenses/by/4.0/). 